\title{
Ecological

\section{A note on the biodiversity of insects collected from a college campus of Jhalawar District, Rajasthan}

\author{
Roopam Kulshrestha and Nita Jain \\ Department of Zoology, Government Post Graduate College, Jhalawar and Department of Zoology, \\ Government Post Graduate College, Kota, Rajasthan India
}

\begin{abstract}
The study of biodiversity of insects was conducted in the college campus which covers around half square kilometer area. One boundary of college campus is along NH12. The major vegetation of college campus is neem, banyan, Asoka and amaltas trees and some ornamental and medicinal plants. The main objective of the study was to determine the insect diversity and the relative abundance of the insect species in the campus. The collection of insects was carried out by using sweep nets, hand picking and beating tray in the month of Feb.-March and Sept-Oct in the year 2012. Species diversity and abundance of insects were investigated in college campus and we recorded insects belonging to 7 orders 16 families and 38 species. The largest number of insect identified were of Lepidoptera followed by Hymenoptera, Odonata, Hemiptera, Orthoptera, Coleoptera and Neuroptera. Anthropogenic activities influenced the abundance of insect orders. Thus, greater numbers of insects were observed in small gardens with a greater proportion of bare soil relative to concrete pathways and places with human interference. The study revealed the higher abundance of butterflies among the insects identified. A total 38 different insect species were recorded giving an indication of the species diversity of the college campus.
\end{abstract}

KEY WORDS: ABUNDANCE, BIODIVERSITY, INSECTS, JHALAWAR

\section{INTRODUCTION}

Biological diversity is one of the most fascinating aspects of biology. Evolution by natural selection has produced, and is still producing different species. Biodiversity also encompasses functioning, intact plant and animal communities and the processes that affects them. Today
India, is occupying a significant space, documenting nearly 7 percent of global faunal diversity. There are 1.4 millions species of insects described in the scientific literature which is $80 \%$ of life currently recorded on earth. The estimation indicates there may be as many as 30-50 million species of insects making this perceives terrestrial orthopodial groups 97\% of global diversity.

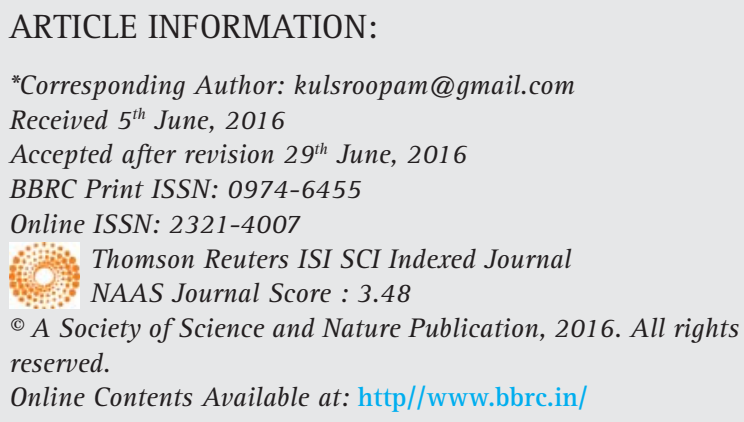


(Erwin, 1982, 1983b, Ghosh, 1990, 1994, Hammond, 1992, Hammond, 1999, Chandra 2011, Patel et.al. (2015) and Ditchkoff, 2016).

Great insect diversity is indeed an intrinsic part of the Earth's ecosystem. They are what make the ecosystems tick, remarked (Samways, 1994). However, the insect fauna of India is vast. In the present study the largest number of species (21) identified was of order Lepidoptera. In India the researches work of Sharma et.al. (2012) in foothills of Itanagar, Arunachal Pradesh; Parandhaman 2012) in different habitats from Tamilnadu part of Western Ghats; Kaneria et.al. (2013) in Bilaspur District, Chhattisgarh; Qureshi et.al. (2013) in District Kupwara from Jammu and Kashmir State; Saikia (2014) in Gauhati University campus, Assam; Arya et al., (2014) in and around Kumaun University, Nainital, Uttarakhand; all these workers have provided valuable information on various insects and butterflies with reference to their diversity and abundance.

A comprehensive account of insect diversity of Sikkim has been provided by Chandra (2011) where insect diversity of Sikkim, was studied. Altogether, 5892 species belonging to 2382 genera under 261 families and 22 orders of Insect have been reported from the state of Sikkim. In an intensive study made by Patel et.al. (2015) in Jabalpur Community Forest Reserve, a total of 774 individual of insects from 13 orders were recorded during the study. A preliminary study on abundance and diversity of insect fauna in Gulbarga District, Karnataka, India was conducted by Belamkar and Jadesh in 2012. A total of 11,318 insects from 6 orders, 26 families and 54 species were recorded.

In present investigation the insects were collected from the Post Graduate Goverment College campus, Jhalawar. Insects live in highly diverse habitats and could be found practically everywhere on the campus. In present study, collection of most of the insects (species) was done, between $1100-0200$ hrs and twice in the year 2012; in the month of Feb.-March and Sept-Oct. Majority of the insects were collected from all sorts of plants: grass, flowers, weeds, shrubs and trees. Some were found around and on the walls of building blocks. The main objective of this study was to collect and identify insect species, diversity and abundance of insects in the college campus, Jhalawar. Vegetation of campus was of mixed type which includes trees, climbers, grass, medicinal plants, shrubs, ornamental plants and herbs. Many groups of insects recognized were: Lepidoptera, Hymenoptera, Odonata, Hemiptera, Orthoptera, Coleoptera and Neuroptera. They are unique in their own way and have an important ecological role for survival of life on Earth.

Most of the insects in this study were collected manually i.e. by sweep netting, hand picking and beating tray or by visual search method. Collected insects were transferred in bottles for killing that contains cotton soaked with ethyl acetate covered with lid. Later on specimens were sorted out into different taxonomic groups. All the specimens were stretched, pinned, labeled and left for 72 hrs to prevent decomposition. As some species dragonflies were sighted in very few numbers in college campus, it was difficult to catch them, but we have taken the best possible photographs of those dragonflies. Identification of insects was done at IARI New Delhi and MPUAT, Udaipur. A total of 38 individuals belonging to 07 orders were recorded from the campus of Government College Jhalawar.

Insects of 07 orders belonging to 16 families 38 species were collected and identified. Maximum species of Lepidoptera identified was 21 in number belonging to 5 families. In other parts of Rajasthan abundance of Lepidoptera individuals was observed. The extensive studies on Lepidopterous insects associated with vegetables were conducted indifferent localities of Aravalli Range of Rajasthan i.e. Mount Abu, Udaipur, Rajsamand, Pushkar, Ajmer, Jaipur, Sikar, Jhunjhunu, Sariska, Alwar, Dausa and Bharatpur during 2008-11.

A total of 38 species of Lepidopterous insects associated with vegetables in Aravalli Range of Rajasthan were recorded, out of 152 species of Lepidopterous insects recorded from India (Sharma, 2011). Further in the present study, number of indentified species was followed by Hymenoptera (5), Odonata (4), Hemiptera (3), Orthoptera (3), Coleoptera (1) and Neuroptera (1). The 5 species of Hymenoptera belonging to 3 families; 3 species of Hemiptera belonging to 2 families were identified.

Likewise number of species of Odonata identified was 4, belonging to 2 families which were captured and identified by Koli et al., in the year 2014 in a study, of south Rajasthan, which explored the diversity and species composition of Odonata.. Odonates were sampled from 13 localities i.e., Pichola lake, Udaisagar lake, Badi lake, Ghasa lake, Menar lake, Badwai lake, Rup sagar lake, Rolitodgarh Wildlife Sanctuary, Sitamata Wildlife Sanctuary, Karmoi river stream in Sitamata WLS, College campus, Rajsmand lake and Meja dam.

In the present study, out of these insects, individuals of the order Lepidoptera: Terias hecabe and Lampides boeticus, were found to be dominant (Table:1.1), while minimum was of beetle (Coleoptera) Chrysocoris chinonsis and (Neuroptera) Crolen species; as shown in the table. In Central India a total of only 10 species of ground beetles were recorded (All the species were recorded for the first time from Melghat Tiger Reserve) Thakare et al., (2013) and in our study we have recorded only one species of beetle. 


\begin{tabular}{|c|c|c|c|c|}
\hline S. NO. & ORDER & FAMILY & GENUS SPECIES & $\begin{array}{l}\text { ABUNDANCE } \\
\text { (Approx. no. of insects) }\end{array}$ \\
\hline 1. & Lepidoptera & Pieridae & Ixias marianne (Linnaeus) & 22 \\
\hline 2. & Lepidoptera & Pieridae & Catopsilia pyranthe & 14 \\
\hline 3. & Lepidoptera & Pieridae & Terias hecabe (Linnaeus) & 152 \\
\hline 4. & Lepidoptera & Pieridae & Catopsilia pomona & 27 \\
\hline 5. & Lepidoptera & Pieridae & Anaphaeis aurota (Febricius) & 12 \\
\hline 6. & Lepidoptera & Pieridae & Eurema laeta (Boisduval) & 16 \\
\hline 7. & Lepidoptera & Pieridae & Appias albina (Boisduval) & 22 \\
\hline 8. & Lepidoptera & Nymphalidae & Junonia lemonias & $25-30$ \\
\hline 9. & Lepidoptera & Nymphalidae & Junonia (Precis) atlites (Linnaeus) & 28 \\
\hline 10. & Lepidoptera & Nymphalidae & Junonia almona & 18 \\
\hline 11. & Lepidoptera & Nymphalidae & Junonia orithya & 37 \\
\hline 12. & Lepidoptera & Nymphalidae & Danaus chrysippus (Linnaeus) & 45 \\
\hline 13. & Lepidoptera & Nymphalidae & Telchinia violae (Febricius) & 4 \\
\hline 14. & Lepidoptera & Nymphalidae & Parantica aglea & 12 \\
\hline 15. & Lepidoptera & Papilionidae & Pachliopta aristolochiae & 8 \\
\hline 16. & Lepidoptera & Papilionidae & Papilio demoleus & 11 \\
\hline 17. & Lepidoptera & Papilionidae & Zetides agamemnon & 12 \\
\hline 18. & Lepidoptera & Lycaenidae & Lampides boeticus & 250 \\
\hline 19. & Lepidoptera & Lycaenidae & Catochrysops enjus & 68 \\
\hline 20. & Lepidoptera & Lycaenidae & Castalius rosimon & 5 \\
\hline 21. & Lepidoptera & Arctiidae & Utethesia pulchella & 3 \\
\hline 22. & Hymenoptera & Apidae & Xylocopa fenestrate & 9 \\
\hline 23. & Hymenoptera & Apidae & Apis florae & 24 \\
\hline 24. & Hymenoptera & Apidae & Apis dorsata & 46 \\
\hline 25. & Hymenoptera & Vespidae & Ropalidia marginata & 38 \\
\hline 26. & Hymenoptera & Sphecidae & Liris species & 9 \\
\hline 27. & Odonata & Lebellulidae & Orthetrum taeniolatum (schreides) & 18 \\
\hline 28. & Odonata & Lebellulidae & Neurothemis intermedia intermedia (romber) & 18 \\
\hline 29. & Odonata & Lebellulidae & Brachythemis cantaminata (febricui) & 22 \\
\hline 30. & Odonata & Coenagrionidae & Ceriagrion coromandelianun (febricui) & 21 \\
\hline 31. & Hemiptera & Pentatomidae & Halys parvus (chopra) & 19 \\
\hline 32. & Hemiptera & Pentatomidae & Erthesina fullo (Thunberg) & 45 \\
\hline 33. & Hemiptera & Lygacidae & Spilostethus pandurus & 55 \\
\hline 34. & Orthoptera & Acrididae & Catantops karnys / pinguis & 20 \\
\hline 35. & Orthoptera & Acrididae & Acrididae exalatata & 28 \\
\hline 36. & Orthoptera & Tettigonidae & Himertula pallisignata & 14 \\
\hline 37. & Coleoptra & Buprestidae & Chrysocoris chinonsis & 2 \\
\hline 38. & Neuroptera & Myrrnelontidae & Creoleon spc. & 16 \\
\hline
\end{tabular}

It is concluded that a small compact area like a segregated college campus supports a diverse butterfly community. Similar type of study on insect biodiversity has been carried out by Grampurohit and Karkhanis (2013). However, the results which are being presented in this paper might be the first comprehensive list of insects in the Jhalawar district. Hopefully, there will be a further research study on the insect biodiversity of this area, in order to get better and comprehensive information on those aspects to be documented for future reference. 


\section{ACKNOWLEDGEMENTS}

We would like to express our heartiest gratitude to Dr. Swamynathan (ICAR Network Project on Insect Biosystematics, Department of Entomology, Rajasthan College of Agriculture, MPUAT), Udaipur and Dr. V. V. Ramamurthy (Insect Identification Service Division of Entomology, Indian Agricultural Research Institute, New Delhi-110012) for helping us in identifying insects up to species level.

\section{REFERENCES}

Amala S. , Rajkumar M. and Anuradha V.(2011) Species Richness of Butterflies in the Selected Areas of Siumalai Hills. Int. J. Pure Appl. Sci. Technol., 6(2), Pages. 89-93

Arya M. K., Dayakrishna and Chaudhary R.(2014) Species richness and diversity of Butterflies in and around Kumaun University, Nainital, Uttarakhand, India. Journal of Entomology and Zoology Studies; 2(3) Pages: 153-159

Belamkar N. V. and Jadesh M. (2014) A Preliminary Study on Abundance and Diversity of Insect Fauna in Gulbarga District, Karnataka, India. International Journal of Science and Research. Volume 3 No.12 Pages:1670-1675

Chandra K. (2011) Insect Diversity Of Sikkim, India Pages 181-206

Ditchkoff S.(2016) Biodiversity and Ecosystem Management, Oklahoma State University.12:1.

Grampurohit B. and Karkhanis H. (2013) Insect Biodiversity At Mangrove Ecosystem. National Conference on Biodiversity :
Status and Challenges in Conservation - 'FAVEO' Pages:108115

Koli V.K. ,Bhatnagar C. and Shekhawat D.S. (2014) Diversity and Species Composition of Odonates in Southern Rajasthan, India. Proc Zool Soc.Springer

Muhammad A. (2009) Diversity, Species Richness And Evenness Of Moth Fauna Of Peshawar. Pak. Entomol.31: 2.

Parandhaman D. (2012) Diversity of butterflies in different habitats from Tamilnadu part of Western Ghats (Lepidoptera: Rhopalocera). Savarimuthu Ignacimuthu et al./ Elixir Appl. Biology 51.Pages: 10861-10865.

Patel D.R. (2015) Diversity and abundance of insect species at Madhya Pradesh forest. International Journal of Multidisciplinary Research and Development; 2(3): Pages: 304-307

Qureshi A.A Bhagat and R.C. and P.C. Pathania (2013) Rhopalocera Diversity (Lepidoptera) of District Kupwara from Jammu and Kashmir State (India). Biological Forum - An International Journal 5(1):Pages:100-106

Samways M.J. (1994) Insect Conservation. EOLSS Publications Sharma G.(2011) Studies on Lepidopterous Insects Associated with Vegetables in Aravali Range, Rajasthan, India. Biological Forum -An International Journal, 3(1) Pages: 21-26

Singh M.P.; Dey S; Singh S. B.(2004) Conservation of biodiversity and natural resources. Daya Publishing House, Delhi.

Thakare V.G.,Zade V.S. and Hegde V.D. (2013) Ground beetles (Coleoptera: Carabidae) of Melghat Tiger Reserve, Central India. New Biological Reports 2(2) Pages: 173-176 